\title{
Analysis of the Management of Non-Tax State Receivables in the Directorate General of Intellectual Property
}

\author{
Desta Herawaty Tarigan* \\ State Development Administration, Study Program Master of Applied, State Financial Management Concentration \\ STIA Lan Jakarta Polytechnic \\ Jakarta, Indonesia \\ *sptdesta@gmail.com
}

\begin{abstract}
The Directorate General of Intellectual Property has revised patent law number 14 of 2001 to number 13 of 2016 but there still have work to be completed by the Directorate General of Intellectual Property. Based on the audit of the Supreme Audit Agency, there are still annual patent maintenance fees that have not been billed to the patent holder, even though the patent has been legally canceled or has been filed for patent cancellation. The unpaid fees become a non-tax state receivable which must be collected by the Directorate General of Intellectual Property. These non-tax state receivables accumulate and are difficult to collect because receivables are discovered after inspection and result in delays in the handling and collection of accounts receivable. This study aims to evaluate the management of non-tax state receivables at the Directorate General of Intellectual Property. The data collection procedure in this study was to conduct interviews and study documents at the Directorate General of Intellectual Property. The research method used is qualitative with a case study approach. The results showed that the receivables value presented was inaccurate because the receivables data had not been verified thoroughly so that the receivables value was corrected. all receivables have become uncollectible accounts and have been transferred to the Directorate General of State Assets Management, and there has been no write-off for receivables that have been designated as potentially uncollectible receivables.
\end{abstract}

Keywords-non-tax revenues, receivable management, audit

\section{INTRODUCTION}

During the Covid-19 pandemic there was a slowdown in economic growth which resulted in a decrease in state revenues. The government continues to strive to recover the national economy by issuing policies that support the optimization of state revenues. In Law Number 17 of 2003 concerning State Finances [1], article 11 states that there are 3 sources of state revenue, namely tax revenue, non- tax revenue and grants. Tax revenue is the main source of government revenue, but taxes are not able to finance all government expenditures, so it is necessary to extract from other sources of revenue. Non- tax revenue contributes the biggest amount after tax revenue. In the 2019 State Budget, it was noted that nontax revenue contributed $17.5 \%$ to total state revenue. The largest non- tax revenue comes from revenues from Natural Resources and other PNBP. According to Law Number 9 of 2018 concerning non- tax revenue [2], non- tax revenue is all central government revenue that does not come from tax revenue. The law also describes the types of non-tax revenues consist of receipts derived from the management of government funds, acceptance of the use of natural resources, acceptance of the results of the management of The Wealth Separated State, acceptance of the Government's services, receipts based on court decisions and those originating from the imposition of administrative fines, receipts in the form of grants which are the right of the Government and other revenues regulated in a separate Law . While it, in the structure of the state budget, non-tax group distinguished on the acceptance of Natural Resources (oil and gas and non-oil natural resources), income from the State Property Separated Other non-tax revenues.

Public Service Agency collection and management of nontax revenue on the Ministry based on Government Regulation on the type and Rates of non-tax revenue in each ministry. Ministry of Law and Human Rights one contributor non-tax revenue Ministry Other World among others derived from service Intellectual Property in the form of a patent application under the Directorate General of Intellectual Property Rights.

Provisions regarding the maintenance of patents are regulated in the Patent Law Number 14 of 2001 concerning Patents [3] which states that for the management of the continuity of the validity of the patent and license registration, the Patent Holder or License of a patent is obliged to pay an annual fee. Payments are made based on a registered number (ID). And Article 115 states that if for three consecutive years the Patent Holder does not pay the annual fee, the patent will be declared null and void as of the end date of the payment obligation for the third year. A period of 3 years is based on the consideration of providing sufficient opportunities for the Patent Holder to consider for himself the continuity of the 
Patent. The Directorate General shall notify the Directorate General of the cancellation of a Patent due to not paying the annual fee to the Patent Holder in writing. The notification shall state the date of expiration of the Patent in accordance with the provisions of this Article. Fees that have not been paid for 3 (three) years are debts that must be paid / repaid by the relevant Patent Holder, which is called patent receivables. Even though Law Number 14 of 2001 has been amended to Law Number 13 of 2016 concerning Patents [4], one of the amendments is that there are no more patent receivables because if the Patent Holder does not pay the patent maintenance fee according to the provisions, the patent will be abolished. However, settlement of patent receivables is still a challenge for the Directorate General of Intellectual Property.

All non-tax revenue that has been collected and received must be deposited in the state treasury. In the case of mandatory non-tax paid on payment owed the end of the financial period, agencies from non-tax revenues recorded as receivables outstanding non-tax revenues in accordance with the type of non-tax revenue. The recording of non-tax Receivables at the ministry must be supported by a valid billing or assessment letter or others document. The management of non-tax receivables is very important as a source of state revenue. For that it needs to be managed properly and optimally.

The problem raised in this research is why the settlement of patent receivables is protracted and still not optimal. For this reason, researchers want to know the procedure for settlement of patent receivables at the Directorate General of Intellectual Property. In 2019, the balance of patent receivables in the financial statements of the Ministry of Law and Human Rights was still quite large and all of them were bad debts. However, an evaluation has not been carried out whether this bad debt still has the potential to be collected or can be submitted for write-off. In the Regulation of the Minister of Finance Number 82 / PMK.06 / 2019, it is stated that the submission of proposals for absolute write-offs of state receivables is made after 2 (two) years have passed since the date of determination of Conditional Write-off. This is also a concern for the Supreme Audit Agency which still includes Patent receivables are a recurring finding where in the Report on the Results of the Audit on Compliance with the 2019 Laws and Regulations, the Supreme Audit Agency includes the management of bad debts on patent receivables in its findings. Settlement of patent receivables must be managed effectively and efficiently, and the presentation must be correct so that the financial statements that are presented are more accountable.

Based on these problems, this study aims to determine the settlement of non-tax receivables that are still on going and the data are not yet accurate. Research is conducted at the Directorate General of Intellectual Property as a subject for the Directorate General of Intellectual Property because the current patent protection is very important to the business world. This research is limited to the completion of the non-tax receivables originating from receivables patents only.
Ellet [5] states that case studies have at least four benefits namely, to evaluate existing performance / results, analysis certain situations, provide solutions to problems at hand, and provide information for decision making. In accordance with Ellet's [5] statement, this research is expected to provide additional information for the Directorate General of Intellectual Property about the factors that cause the settlement of patent receivables to be not optimal so that they can carry out evaluation and corrective steps towards efforts to settle non-tax receivables sourced from patent receivables that have been made so far.

\section{LITERATURE REVIEW}

To find comparisons and to find ideas in research, the authors conducted a study of several previous studies. As Rompas et al. [6] which conducted research on the management of accounts receivable and the loss of uncollectible accounts receivables at PT Bank Rakyat Indonesia. The research method used is descriptive qualitative research with observation and interview data collection methods. The result of this research is that the management of accounts receivable at PT Bank BRI is already good, but it is necessary to increase supervision in the management of accounts receivable by using the 5 Cs (Character, Capacity, Capital, Collateral and Condition). Wuwungan et al. [7] which conducts research into the factors that influence the process of settlement of accounts receivable by State Assets and Auction Service Office in Manado. The research method used is the method of application of science and technology with data collection by means of interview. The results of this study are the factors that affect the settlement of accounts receivable are incomplete data from the debt guarantor, no collateral, and the business of the debt guarantor is not working properly and there is no scheduled reconciliation with State Assets and Auction Service Office. Amelia [8] who conducted research on the factors causing uncollectible accounts at PT Perkebunan Nusantara III (Persero) Medan. In this research, method used is descriptive qualitative with data collection methods by means of interviews and document study. The results of this study concluded that the factors in the occurrence of uncollectible accounts were internal factors, namely weak credit administration systems, weak credit information systems and irregularities in the implementation of credit procedures. Meanwhile, external factors are due to the decline in economic conditions, the failure of the debtor's business, debtors who run away and debtors who have bad intentions to pay off their obligations. The research mentioned above was not carried out in the government sector.

Mardiasmo [9] states that receivables are the right to receive payments from parties who are obliged to pay. Kasmir [10] defines receivables as a claim against the purchaser and certain parties which completion is expected in the form of cash and others for the payment of money, goods, or services that have been submitted at an earlier time. According to the Treasury Law Number 1 of 2004 concerning State Treasury [11], receivables are stated as the amount of money that must 
be paid to the Government arising from an agreement or from the prevailing laws and regulations or other legal consequences. Whereas in Regulation the Government of Number 71 Year 2010 concerning the Government Accounting Standards, receivables included in current assets category along with cash and cash equivalents, short term investments and inventories.

Arikunto [12] surfaced right that the word of "management" can be equated with the management, which means that also the setting or management. Management is defined as a series of job or the work done by a group of people to do right series of work in achieving certain goals. Atmosudirjo [13] defines the word management is the control and utilization of all resource factors according to a plan necessary to complete a certain goal. Meanwhile, there is an Explanation of Government Regulation in Lieu of Law No. 49 of 1960 concerning the committee for state account receivables states that the word "management" is broader than "settlement" because the committee for state account receivables is not only tasked with settling state receivables but more than that, so it is felt necessary to change the term settlement to management. So that management (receivables management) can be interpreted as a process of planning, organizing, directing, and monitoring in the form of claims to debtors who carry out the consequences of sales transactions on credit. Accounts receivable management is responsible for monitoring receivables that have arisen with the aim of not exceeding the allowable limit [14].

In this study the theory yes ng used is the theory of New Public Management introduced by Hood [15]. Through Home Visits emphasize to the action changes to promote the establishment of effective administration government if and efficient. The concept of New Public Management emphasizes the management sector public which is not performanceoriented policy. Hood [15] states that New Public Management discount seven main elements, namely management professional management in the public sector, their performance measurement standards are clear, a greater emphasis on the control of output, splitting the working units in the public sector, competition greater emphasis in the public sector, an emphasis on shifting private sector management practices into the public sector, and a greater emphasis on discipline and austerity in the use of resources.

\section{RESEARCH METHODS}

In this study the authors conducted research using qualitative methods with a case study approach. Qualitative research is a research approach to explore and understand the meaning of an individual or group related to social or humanitarian problems [16]. According Sugiyono [17], approach case study collected information on issues $\mathrm{y}$ ang examined later processed into data to find solutions to the problem are revealed.

Data collected in this study are primary data, namely data in the form of verbal or spoken words, gestures or action carried out by trustworthy subjects, in this case the research subjects (informants) with regard to with the variables studied [18]. Technique data collection can be done by way of a test, interview (interview), observations (observation) and documentation as well as pictures or a combination of these methods [19]. Data collection techniques in this research are interviews and document studies. Interview is a way of collecting data through oral communication activities in structured, semi-structured, and unstructured forms. Interview structured interview is a form that has been directed with a number of questions closely. Interview semi-structured, although the interview has been guided by a list of questions it is possible that the idea raised new questions arise spontaneously within the context of the conversation he did. An unstructured (open) interview is an interview in which the researcher only focuses on the main of the problem which appear to be tied to a certain format tightly [20]. In this study the authors used semi-structured interviews to obtain more indepth and comprehensive information from informants. The steps taken by the writer in conducting the interview are compiling a list of questions in accordance with the main task of the informant related to the management of accounts receivable as an interview guide, contacting the informants for the willingness of time to conduct interviews. The method of documentation, which is looking for data about things or variables in the form of notes, transcripts, books, newspapers, magazines, inscriptions, meeting minutes, notes, agendas, and so on [18]. The documentation that the authors do in this research is to collect written data in the form of reports, letters, and regulations related to accounts receivable management. In addition, the authors also collect data in the form of activities carried out in an effort to optimize the management of non-tax receivables originating from patent receivables at the Office of the Directorate General of Intellectual Property.

In this study, the authors use technique data processing using a qualitative descriptive which the authors gathered data from the object under study and present since before entering the field to finish in the field. Data analysis in this study was carried out at the time of data collection during interviews, observation and documentation. Data analysis is the process of systematically searching and compiling data obtained from interviews, field notes, and other materials so that they can be easily understood, and the findings can be shared with others [17]. Results of the study documents and interviews compared and described to be able answer research problems.

\section{RESULTS AND DISCUSSION}

From the results of the problem formulation in the research, an analysis of the management of Non-Tax State Revenue Receivables is carried out at the Directorate General of Intellectual Property. After conducting interviews and study documents related to receivables, it was found that the management of accounts receivable at the Directorate General of Intellectual Property did not yet have a business process for settling receivables. According to Atmoko [21], Standard Operating Procedure (SOP) is a guideline or reference for 
carrying out work tasks in accordance with the functions and performance assessment tools of government agencies based on technical indicators, administrative and procedural in accordance with work procedures, work procedures and work systems in the work unit concerned. In accounts receivable management activities have used an application system. The system in a business process is very important to simplify and increase the reliability of an event. Before using the application, the administration of patent receivables was done manually. The technology-based application system currently in use is the Information System for the Administration of Non-Tax State Revenue Receivables, which is used for reporting receivables and checking maintenance costs. Meanwhile, the Teman Kita application is used to check the history of patent holders and the administration of accounts receivable and to process accounts receivable settlement. And the E-Dashboard application to check the amount of patent holders' receivables. This application can make it easier to make decision letters, billing letters, repayment, and reporting. Through the application, however, the system has not been perfectly integrated with the parts related to the management of accounts receivable. The manual work takes place in data correction activities, reporting the value of receivables based on patent holders, checking receivables based on names of patent holders and administering accounts receivable. In addition, the report data generated from the application still requires further analysis.

Non-tax State Revenue Receivables originating from patent receivables are receivables that appear as the implementation of Law Number 14 of 2001 concerning Patents [3]. With the amendment of this Law Number 13 Year 1016 concerning Patents [4], new transactions that cause receivables to no longer exist because if the patent holder does not increase his obligations according to a predetermined period of time, the patent will be eliminated. This means that the payment of receivables from the Directorate General of Intellectual Property should not increase because the new provisions have already been implemented. However, due to the weak administrative system that is carried out manually, there is still an increase in the value of receivables because several patents that have been null and void and patent cancellations at the request of the patent holders themselves still have outstanding amounts that must be paid according to the old law.

In collecting activities, the Directorate General of Intellectual Property uses an application and is sent to the patent holder by letter and a personal visit to the Patent Holder's Proxy office which is registered in the patent application database for the first time. According to Law Number 13 of 2016 [4], Proxy is an intellectual property consultant who resides or has a permanent domicile in the territory of the Republic of Indonesia. Kasmir [6] says that there are 4 ways to collect, namely through letters, telephone, personal visits, and actions. juridical. Efforts to collect by telephone have not been carried out because considering the domicile of $95 \%$ of patent holders is abroad and personal data of patent holders is very limited. According to Law Number 13 of 2016 [4], a Patent Holder is an inventor as the owner of the
Patent, the party who receives the right to the Patent from the owner of the Patent, or other party who further receives the right to the Patent which is registered in the general list of Patents.

Halim [22] states that the factors that cause bad debt are internal factors and external factors. Internal factors consist of weak administrative systems, weak information systems and irregularities in the implementation of credit granting procedures. Meanwhile, external factors are caused by a decline in economic activity, debtors and debtors' business failures experiencing disasters. At the Directorate General of Intellectual Property, due to the domicile of the patent holder who is abroad, there are difficulties in collecting. Efforts that have been made to overcome this problem are by asking for assistance from representative offices in countries where the payer is registered. Apart from that, they also made direct visits to several countries that had patent receivables. However, based on the data on the results of receiving receivables in full, from the results of the visit, the results are still not maximal. In 2018 and 2019, the Director General of Intellectual Property issued a circular regarding the Affirmation of the Obligation of the Annual Patent Fee Payable for Patent Holders requesting the patent holder to pay off the annual fee payable within 6 months from the date of the letter. This effort proved to be quite effective with the increase in the payment of receivables received from the payer.

In the Regulation of the Minister of Finance Number 240 of 2016 concerning Management of State Receivables [23], it is stated that if the maximum effort has been made by the ministry, the management will be submitted to the management of State Receivables to the Branch Committee through the Office of State Assets and Auction Services. Submission of the management of patent receivables from the Directorate General of Intellectual Property to the State Property Services Office is still done manually. This has resulted in discrepancies in the number of documents and differences in data between the Directorate General of State Assets and Auctions, which are still being reconciled regularly.

In the activity of repaying the payment of receivables, the payment is still done manually, not host to host. Receivables whose management is still at the Directorate General of Intellectual Property will be received through the account of the Receiving Treasurer of the Directorate General of Intellectual Property. Meanwhile, for bad debts that have been submitted to the State Asset and Auction Service Office, the payment by the obligator is made through the account of the Recipient Treasurer of the State Wealth and Auction Service Office. After the identification and verification process, the Receiving Treasurer will deposit the principal debt into the state treasury. This principal debt is recorded as Non-Tax State Income. However, many debtors make payments without confirming and payment information that is read on the Receiver Treasurer account is very limited for identification and verification. In addition, there are still differences in the value of receivables recorded at the Directorate General of Intellectual Property and the State Property and Auction 
Service Office due to the correction in the value of the receivables.

In settling non-tax state revenue receivables, the Directorate General of Intellectual Property has made various efforts and attempted to carry out management in accordance with the recommendations of the Supreme Audit Agency but has not yet evaluated and monitored the indicators of success of the efforts made towards settling non-tax state revenue receivables. This is because there is no set target for settlement of accounts receivable. However, the Supreme Audit Agency's Audit Results Report in 2019 still includes patent receivables in its findings, namely that the Directorate General of Intellectual Property does not yet have a list of patent receivables per patent holder who is still active and inactive. The current application can only present a simple list of accounts receivable based on patent holders. Furthermore, the data on patent receivables presented are not valid due to manual activities. This has resulted in efforts to write off potentially uncollectible receivables that require further data verification and coordinate with the Office of State Assets and Auction Services on a scheduled basis.

\section{CONCLUSION}

Based on the findings and results of data analysis, it is found that the management of non-tax state revenue receivables at the Directorate General of Intellectual Property has carried out efforts to settle accounts receivable properly. However, it experienced delays due to weak administrative systems and limited information technology systems. Accounts receivable management activities that are carried out without using Standard Operating Procedures result in officers managing accounts receivable having no guidelines and lack of understanding in carrying out daily tasks. In addition, reconciliation is still needed to update data on accounts receivable, whether the management is still at the Directorate General of Intellectual Property or those that have been submitted to the State Property Services Office and Auctions. So that the administrative system must be improved to facilitate tracking data on patent receivables.

\section{REFERENCES}

[1] Ministry of the Republic of Indonesia, Undang-Undang Republik Indonesia Nomor 17 Tahun 2003 tentang Keuangan Negara, Jakarta, 2003.
[2] Ministry of the Republic of Indonesia, Undang-Undang Republik Indonesia Nomor 9 Tahun 2018 tentang Penerimaan Negara Bukan Pajak, Jakarta, 2018.

[3] Ministry of the Republic of Indonesia, Undang-Undang Republik Indonesia Nomor 14 Tahun 2001 tentang Paten, Jakarta, 2001.

[4] Ministry of the Republic of Indonesia, Undang-Undang Republik Indonesia Nomor 13 Tahun 2016 tentang Paten, Jakarta, 2016.

[5] W. Ellet, Case study handbook. Boston, massachusetts: harvard business scholl press, 2007

[6] R.R. Rompas, I. Elim, and I.G. Suwetja "Analisis Pengelolaan Piutang Dan Kerugian Piutang Tak Tertagih Pada Pt. Bank Rakyat Indonesia Cabang," Going Concern: Jurnal Riset Akuntansi, vol. 13, no. 03, 2018.

[7] G.T. Wuwungan, S.D. Rawis, and V.Z. Tirayoh, "Iptek Faktor-faktor yang Mempengaruhi Proses Penyelesaian Piutang Negara oleh Pupn di Kpknl Manado," Jurnal Ipteks Akuntansi Bagi Masyarakat, vol. 2, no. 2, 2018.

[8] S. Amelia, Analisis Faktor-Faktor Penyebab Piutang Tak Tertagih Pada PT. Perkebunan Nusantara III (Persero) Medan (Doctoral dissertation, Universitas Islam Negeri Sumatera Utara), Medan, 2019.

[9] Mardiasmo, Akuntansi sektor publik, Yogyakarta: ANDI, 2018.

[10] Kasmir, Bank dan lembaga keuangan lainnya, Jakarta: PT Raja Grafindo Persada, 2015.

[11] Ministry of the Republic of Indonesia, Undang-Undang Republik Indonesia Nomor 1 Tahun 2004 tentang Perbendaharaan, Jakarta, 2004.

[12] S. Arikunto, Prosedur penelitian suatu pendekatan praktek, Jakarta: Rineka Cipta, 2010

[13] P. Atmosudirjo, Manajemen dasar pengertian dan masalah, Jakarta: Rineka Cipta, 2005.

[14] L.S. Atmaja, Teori dan praktik manajemen keuangan, Yogyakarta: CV. Andi, 2008

[15] C. Hood, "A public management for all seasons?," Public administration, vol. 69 , no. 1, pp. 3-19, 1991

[16] J.W. Creswell, Research design qualitative, quantitative, and mixed methods approaches, Sage Publication, 2014

[17] Sugiyono, Metode penelitian kuantitatif, kualitatif, dan R\&D, Bandung: CV.Alfabeta, 2017.

[18] S. Siyoto, Dasar metodologi penelitian, Yogyakarta: Literasi Media Publishing. 2015.

[19] M.S. E. Barlian, Metodologi penelitian kualitatif \& kuantitatif, Padang: Sukabinapress, 2016.

[20] Suyitno, Metode Penelitian Kualitatif: Konsep, Prinsip Dan Operasionalnya, Tulungagung: Akademia Pustaka, 2017.

[21] T. Atmoko, Standar operasional prosedur (SOP) dan akuntabilitas kinerja instansi pemerintah, Bandung: Unpad, 2011.

[22] Halim, Akuntansi sektor publik akuntansi keuangan daerah, Jakarta: Salemba empat, 2002

[23] Ministry of the Republic of Indonesia, Peraturan Menteri Keuangan Nomor 240/PMK.06/2016 tentang Pengurusan Piutang Negara, Jakarta 2016 